\title{
ONLINE EXTREMISM \\ CHALLENGES AND OPPORTUNITIES \\ IN THE WESTERN BALKANS
}

\author{
MILO COMERFORD AND SIMEON DUKIC
}

\section{WESTERN BALKANS SERIES}

${ }^{66}$ Extremist ideologues are not constrained to country-level influence. Rather, online extremist propaganda in the Western Balkans exploits and draws on regional narratives and demographics."

\section{FAST FACTS Context}

$\rightarrow$ The unique demographics and history of the Western Balkans mean that online extremism presents a challenge that is regional, traversing state borders and the reach of individual governments.

$\rightarrow$ Western Balkans countries must be alert to extremist groups, polarizing forces, and hostile state actors co-opting digital platforms to seize on anxieties and grievances emerging across societies, positing supremacist and violent solutions.

$\rightarrow$ The threat from online extremism in the Western Balkans crosses border jurisdictions, which makes cross-national cooperation and support of neighboring countries
The Western Balkans faces a double challenge from online extremism. Online platforms are facilitating the specific targeting of the region by diverse international extremist narratives. Meanwhile regional histories and geopolitics are being appropriated to justify extremist actions and narratives around the world. This dynamic was particularly clear in March 2019, when Brenton Tarrant carried out a devastating terrorist attack on Muslim places of worship in Christchurch, New Zealand. As Tarrant Facebook livestreamed the lead up to the attack, a Serb nationalist song with roots in the Yugoslav Wars-and more recently appropriated as an anthem among the international alt-rightcould be heard playing in the background. ${ }^{1} \mathrm{His}$ guns also referenced the region, daubed with the names of

1 Murtaza Hussain, "From El Paso to Sarajevo: How White Nationalists have been Inspired by the Genocide of Muslims in Bosnia," The Intercept, September 1, 2019, https://theintercept. com/2019/09/01/bosnian-genocide-mass-shootings/ 
historical figures from the Balkans who had resisted Ottoman invasion, and framing his actions as part of a parallel resistance against "Islamization."

The Western Balkans' presence in a global far-right online subculture tied to the radicalization of the Australian Tarrant may seem incongruous. However, this phenomenon is part of a wider trend that underscores the growing challenge posed by the proliferation of transnational extremist ideologies on online platforms, both violent jihadist and extreme right wing. In the Western Balkans, this poses a number of specific risks.

\section{Online Extremism and the Western Balkans}

The unique demographics and history of the Western Balkans mean that online extremism presents a challenge that is fundamentally regional, traversing state borders and the reach of individual governments. Extremist ideologues are not constrained to country-level influence. Rather, online extremist propaganda in the Western Balkans exploits and draws on regional narratives and demographics. Many Western Balkans extremist ideologues, for example, have followings across the region that correspond largely with linguistic lines-ethnic Albanian Salafijihadist clerics from Kosovo also have an influence in Albanian language communities in Albania and North Macedonia, ${ }^{2}$ while supremacist Serbian nationalist narratives target Serb populations across Serbia, Bosnia and Herzegovina, Kosovo, and Montenegro. Such regionalized extremist narratives cannot be detached from legacies of conflict and longstanding interethnic tension within the region.

Outside of the region, international extremist influencers use the web to target audiences in the Western Balkans with a plethora of international websites propagating content in local languages gaining significant penetration in the region's online space. Neo-fascist Croatian groups, for instance, are propagating extremist narratives aimed at diaspora communities within the Western Balkans, seeking to rewrite Croatia's World War II Ustasa legacy. ${ }^{3}$

Meanwhile small elements of diaspora communities in Western Europe, North America, and Australia play a central role in following, and propagating, Western Balkans-based extremism online. ${ }^{4}$ Further afield, Islamist extremist narratives are also targeted at Western Balkans populations. IslamHouse, a prominent Gulf-based website hosting content from a number of Islamist extremist clerics, hosts over nine thousand items of content in Western Balkan languages (compared to seven thousand English-language files). In 2015, the US-based white supremacist portal, Stormfront, boasted 180,000 posts on its southeast Europe-focused forum, largely on the Western Balkans. At the time, Serbia and Croatia showed some of the highest proportional search interest in Stormfront globally according to data from Google Trends. ${ }^{5}$

2 Vesë Kelmendi, and Rudinë Jakupi, Countering the Myths of IS: How to Counter the IS Narrative Online? The Case of AlbanianSpeaking Countries, Kosovo Centre for Security Studies, 2019, http://www.qkss.org/repository/docs/Countering-ISIS-mythseng 724280.pdf.

3 During WWII part of the Yugoslav Kingdom was ruled by a Nazi puppet-state led by the Croatia Ustata regime which was responsible for mass atrocities against Jews, Serbs and Roma. See more on diaspora groups: Sven Milekic, "Croatia's Far Right Draws Strength from Diaspora", Balkan Insight, 5 January 2018, https://balkaninsight. com/2018/01/05/croatian-far-right-draws-strength-from-diaspora-01-04-2018/

4 "Balkan Terror Trials Reveal Links to Western Europe", Balkans Investigative Research Network, January 9, 2018, https://balkaninsight.com/2018/01/09/balkan-terror-trials-reveal-links-to-western-europe-01-08-2018/

5 Joseph Bernstein, "The Internet's United Nations Of White Nationalists", Buzzfeed News, June 24, 2015, https://www. buzzfeednews.com/article/josephbernstein/the-internets-united-nations-of-white-nationalists 
The online space is also bringing region-specific extremist narratives to the world stage. These narratives frame the Western Balkans, with its unique religious and cultural diversity, as a front line in a clash of civilizations between the Christian and Islamic worlds. In a polished 2015 propaganda film, ISIS declared the Western Balkans the next "frontier" for global jihad to both the region and its global audiences. The narrative it amplifies in the video is that Muslims have been long subjugated by the "atheist" communist Albanian and Yugoslav states and then suffered crimes against humanity by Christians during the Yugoslav wars. On the other end of the extremist spectrum, one UK-based self-styled "Christian militant order" claimed to be waging an "online war" in the region, purporting to reach an online audience of tens of millions with its videos in Serbian and Croatian. ${ }^{6}$ The group also provided offline support for Kosovo-based groups, issuing military-grade hardware and clothing to support the "front line in the fight to protect Christendom from Islamist invasion." ${ }^{7}$

\section{Relevance to Policy and Practice}

Attempts by foreign and domestic state and non-state actors to promote destabilization and manipulate divisive regional issues have the potential to lead to increased ethnic discord as well as potential vulnerability to radicalization in the Western Balkans. ${ }^{8}$ This is especially true in crisis scenarios, such as the COVID-19 global pandemic, which various groups are exploiting to stir panic and antagonism between different local communities. ${ }^{9}$ Western Balkans countries must be alert to extremist groups, polarizing forces, and hostile state actors co-opting digital platforms to seize on anxieties and grievances emerging across societies, positing supremacist and violent solutions. But they must also understand the parallel challenge of the export and instrumentalization of Western Balkans narratives by extremist groups outside of the region.

Currently, our ongoing analysis suggests that content-removal based counter-responses are not working, in part due to an inadequate understanding of the online threat environment, a lack of effective cooperation between government, civil society, and tech companies, and the movement of illicit online activity to encrypted messaging platforms. Banned groups and individuals prosecuted under terrorism charges have maintained an online presence, despite offline government efforts to curb their operations. For example, "social media jihadists" continue to use Facebook to freely share audio-visual material and quotes from sermons from radical imams currently serving prison sentences for recruiting individuals to serve the ranks of ISIS. ${ }^{10}$ While the issue of the prevention, mitigation, and regulation of online extremism is a global one, there are a number of regionspecific considerations relevant to effective policy and practitioner responses.

6 Jelena Cosic, Lawrence Marzouk, and Ivan Angelovski, “British Nationalist Trains Serb Far-Right for 'Online War,'” Balkan Insight, May 1, 2018, http://www.balkaninsight.com/en/article/british-nationalist-trains-serb-far-right-for-online-war--04-30-2018

7 Cosic, Marzouk, Angelovski, "British Nationalist."

8 Sophie Eisentraut and Stephanie de Leon, Propaganda and Disinformation in the Western Balkans: How the EU Can Counter Russia's Information War, Konrad Adenauer Stiftung, Berlin: 2018, p. 3-4, http://www.kas.de/wf/doc/kas 51729-544-2-30. pdf?180306092933.

9 Albana Shehaj, "After the Pandemic: Perils and Promise for Western Balkans," Balkan Insight, April 20, 2020, https://balkaninsight.com/2020/04/20/after-the-pandemic-perils-and-promise-for-western-balkans/

10 Regional Cooperation Council, “Balkan 'Social Media Jihadis' More Dangerous than Ex-Fighters," December 20, 2019, https:// www.rcc.int/p-cve/news/259/balkan-social-media-jihadis-more-dangerous-than-ex-fighters 


\section{Countering online radicalization has been held up as a priority by Western Balkan governments: ${ }^{11}$}

" Serbia's CVE strategy affirms the importance of counter-messaging to counter online radicalization.

» The Macedonian strategy discusses capacity building for local and religious communities to counter online extremism.

» The Bosnian strategy emphasizes the importance of monitoring the online space, counternarratives, and limiting online propaganda.

» The Albanian national strategy lays out a two-pronged approach to discredit, and in turn mitigate the influence of extremist propaganda.

» The Kosovo strategy's section on online radicalization states that ISIS has been effective in providing online space to discuss and craft messages to seek recruits effectively.

» The Montenegrin strategy proposes the establishment of an Internet Referral Unit to coordinate the identification of terrorist and violent extremist content with partners.

However, despite prioritization, there is little evidence of concrete initiatives and government-led activities to counter online extremist narratives, either regionally or at a national level.

While there have been a number of grassroots counter-narrative efforts, largely from Islamic groups seeking to rebut extremist religious interpretations, these efforts do not always benefit from domestic or international expert advice on strategic communications or from sufficient resources and support to effectively counter the threat from extremist group messaging. For example, one counter-narrative portal, Fol Tash (Speak Now), run by Islamic theologians, is trying to counter Islamist extremist narratives, but has been limited in its ability to reach and engage vulnerable audiences that might be most at risk from violent Islamist propaganda. ${ }^{12}$ Reflective of a broader global deficit, efforts to counter Western Balkans-focused far-right extremism online

11 Council of Ministers of the Republic of Albania (Decision no. 930), Albanian National Strategy: Countering Violent Extremism, Official Gazette of the Republic of Albania (203/2015), November 18, 2015, unofficial translation, https://cve.gov.al/ wp-content/uploads/2018/11/strategjia-2018-me-ndryshime.pdf; Republic of Kosovo, Office of the Prime Minister, Strategy on Prevention of Violent Extremism And Radicalisation Leading to Terrorism 2015-2020, (Prishtina: September 2015), https://wb-iisg.com/wp-content/uploads/bp-attachments/6122/STRATEGY-on-PVERLT parandalim - ENG.pdf; Bosnia and Herzegovina, Council of Ministers, Strategy of Bosnia and Herzegovina for Preventing and Combating Terrorism 2015-2020, (Sarajevo: 2015), https://wb-iisg.com/wp-content/uploads/bp-attachments/6102/STRATEGIJA ZA BORBU PROTIV TERORIZMA ENG.pdf; Government of Montenegro, Ministry of Justice, Countering Violent Extremism Strategy 2016-2018, (Podgorica: December 2015), https://wb-iisg.com/wp-content/uploads/bp-attachments/6160/Countering-violent-extremismstrategy-2016-2018.pdf; Government of the Republic of Macedonia National Committee for Countering Violent Extremism and Countering Terrorism, National Counterterrorism Strategy of the Republic of Macedonia (2018-2022), (Skopje: February 2018), https://wb-iisg.com/wp-content/uploads/bp-attachments/6135/ct national strategy eng translation sbu.pdf; Government of the Republic of Serbia, National Strategy for the Prevention and Countering of Terrorism for 2017-2021, https:// wb-iisg.com/wp-content/uploads/bp-attachments/6200/Serbian-National-Strategy-for-the-prevention-and-countering-ofterrorism-for-2017-2021.docx.pdf

12 Kelmendi and Jakupi, Countering the Myths of IS. 
were even less prevalent. ${ }^{13}$ Generally, across social media and the wider web, online counterefforts have largely failed to gain traction and effectively contest extremist content in the online space.

Recognizing these deficits and gaps in regional and global responses, this Policy Note provides recommendations for policymakers and practitioners seeking to address and counter extremist activities and narratives focused on the Western Balkans in the online space before they create more harm.

\section{Policy Recommendations}

\section{Build our understanding of the dynamic threat landscape.}

An ongoing picture of the evolving threat is urgently required to inform strategic and effective responses from government, practitioners, civil society, and the private sector to effectively compete with violent extremist ideologies online and offline. As such, developing a robust data and response infrastructure is crucial. An improved data picture will allow governments to better understand the online harms associated with extremist narratives, disinformation and hate speech, and to identify the networks key to disseminating them, all the while ensuring that human rights and privacy are respected. It is especially key that such all of society efforts are transparent by design to protect against their potential co-optation for political goals.

Policymakers also need to recognize and respond to this changing landscape and the evolving organizational dynamics of violent extremism. In particular, governments must develop policy and legal frameworks that adequately address the increasingly decentralized, post-organizational and "crowdsourced" nature of far-right terrorism and ensure that they are not overly reliant on proscribed terrorist groups, which fail to capture the diversity of the contemporary online violent extremism threat. In parallel, governments should pursue greater efforts to respond to legal, but nonetheless harmful, content, such as online hate speech, by considering the applicability of a risk-based "duty of care" approach to encouraging platform regulation. This approach should focus on preserving user safety as well as helping civil society responses with greater resourcing and strengthened capacities to empower credible voices to fill this crucial gap. ${ }^{14}$

\section{Invest in regional expertise to address language blind spots.}

Both jihadist and far-right extremist content in Western Balkan languages are prevalent in online spaces, with content in Albanian, Serbian, and Bosnian readily accessible on both social media platforms and through search engines. ${ }^{15}$ While global technology firms purport to deliver a

13 Jacob Davey, Henry Tuck and Amarnath Amarasingam, "An imprecise science: Assessing interventions for the prevention, disengagement and de-radicalisation of left and right-wing extremists", ISD Global, November 2019. https://www.isdglobal. org/wp-content/uploads/2019/11/An-imprecise-science.pdf

14 An example of this type of programming is ISD's Online Civil Courage Initiative, which works across Europe to upskill and upscale civic responses to hate and extremism. https://www.isdglobal.org/programmes/communications-technology/ online-civil-courage-initiative-2-2/

15 Recent research on online extremism in the Western Balkans region has been conducted by a range of experts including Adrian Shtuni, the Tony Blair Institute for Global Change, Moonshot CVE, the Kosovar Center for Security Studies, and the Balkans Investigative Research Network. 
consistent and standardized experience to users globally, effective platform governance requires a localized understanding of language and culture. As such, when implementing scaled responses to online extremism, global tech firms should invest in bolstering human subject matter expertise to ensure accurate understanding of the threats and challenges in the Western Balkans and strengthen policy enforcement capabilities and opportunities for redress. Since most social media companies do not have representatives in the Western Balkans, it is key to explore methods to strengthen cooperation with governments to jointly establish strategies to counter extremist messaging. A transparent process between governments and tech companies, in consultation with experts and civil society, should determine which online challenges meet the required thresholds for legal and regulatory action, in full respect of human rights.

\section{Move beyond content moderation.}

Considerations around the regulation of technology platforms must move beyond just content moderation to addressing the algorithmic amplification of extremist messaging and the wider ecosystem of online extremism, including how search and recommendation algorithms may be guiding people towards extremist content online. While small steps have been made towards broadening counter efforts beyond just content removal, systematic efforts have not gotten off the ground. Recent releases from Facebook found limited responses by the company to deeper algorithmic challenges around online extremism, despite internal research in 2016 showing "64\% of all extremist group joins are due to [the platform's] recommendation tools." 16

\section{Develop a regional response to a regional challenge.}

The threat from online extremism in the Western Balkans crosses border jurisdictions, which makes cross-national cooperation and support of neighboring countries key. This is especially important with language communities that stretch across borders. This challenge is recognized in the Joint Action Plan on Counter-Terrorism in the Western Balkans where governments in the region have committed to addressing terrorist content online by referring terrorist content to internet companies, and empowering civil society partners to develop effective alternative narratives. ${ }^{17}$

However, there is little detail on concrete mechanisms for collaboration. Western Balkan countries have flexibility in finding joint solutions to this problem. Establishing a regional task force that brings together relevant government departments, including law enforcement and electronic communications agencies, to identify regional threats, share experiences, and develop coordinated responses would enhance efforts to fight exploitation of the internet by extremist and terrorist actors. This could build on bi-annual EU-organized meetings for national P/CVE coordinators aimed at encouraging such collaboration. Bringing together policymakers and cross-sector experts to share knowledge and better understand the potential impact of responses to online harmsincluding digital regulation, digital citizenship education, and communications interventions-will

16 Jeff Horwitz and Deepa Seetharaman, "Facebook Executives Shut Down Efforts to Make the Site Less Divisive," Wall Street Journal, May 26, 2020, https://www.wsj.com/articles/facebook-knows-it-encourages-division-top-executives-nixed-solutions-11590507499

17 "Joint Action Plan on Counter-Terrorism for the Western Balkans," European Commission, October 5, 2018, https://ec.europa. eu/home-affairs/sites/homeaffairs/files/news/docs/20181005 joint-action-plan-counter-terrorism-western-balkans.pdf 
help to undermine and counter the pernicious effects of online disinformation, hate speech, and extremism. $^{18}$

\section{Partner with broader civil society and local communities.}

A recent British Council report on extremism in the Western Balkans finds that surveyed individuals believe that counter-narratives need to be incorporated in strategic preventive programming in the region. ${ }^{19}$ Nevertheless, Western Balkans states suffer from relatively low public trust rates in national government, so the effectiveness of any government strategic communications plan without the buy in and support of wider civil society will be limited. ${ }^{20}$ Countering violent extremism efforts should employ a whole of society approach, to ensure there is community buyin and empowerment of civil society efforts to tackle violent extremism, which can bring unique resource, resonance, and credibility to such initiatives. Additionally, cities and local communities need to be engaged in this endeavor because extremism is manifested differently in different localities, and local authorities and organizations can offer tailor-made responses based on the unique context. ${ }^{21}$

There are some instructive local examples for what such a whole-of-society approach might look like in practice. The Strong Cities Network (SCN) has been supporting the establishment and operationalization of a "Local Prevention Network" model for driving municipality-led and civil society-supported approaches in Kumanovo, North Macedonia. In this context a multi-stakeholder entity called the Community Action Team is mandated to develop, coordinate, and deliver local strategies in line with the National CVE Strategy, as well as jointly plan and implement activities with governmental and non-governmental organizations tailored to key local priorities. ${ }^{22}$ The Centre for Common Ground has also supported the development of Community Action Teams in the municipalities of Čair (Skopje), Gostivar, and Kičevo in North Macedonia, building on the local prevention model. ${ }^{23}$

\section{Promote digital citizenship skills through civic education.}

The Media Literacy Index, compiled by the Open Society Institute, suggests that the Western

18 ISD's Digital Policy Lab and Policy Planners Network seek to build an international 'community of practice' among policy makers and technology experts around digital policy issues https://www.isdglobal.org/programmes/policy-government-advisory/ policy-planners-network/

19 Vlado Azinović, Regional Report: Understanding Violent Extremism in the Western Balkans, British Council, 2018, https:// www.britishcouncil.me/sites/default/files/erf report western balkans 2018.pdf

20 "Serbia the only WB country with more trust in the government than in the EU," European Western Balkans, August 6, 2019, https://europeanwesternbalkans.com/2019/08/06/serbia-the-only-wb-country-with-more-trust-in-the-government-than-in-the-eu/

21 The Strong Cities Network, a global network of mayors, municipal officials, and practitioners devoted to sharing best practices on countering violent extremism and polarisation, has a membership of 44 municipalities across the region that are devoted to the creation of resilient localities. It can facilitate the strengthening of partnerships and the development of strategic communication for cities. Moreover, through its Young Cities programming, the network has supported youth groups to develop youth-led community-based initiatives, some of them in the form of counter-narrative campaigns.

22 Besim Dogani and Nayla Joy-Zein, "SCN's Local Prevention Network Model Expands to the Western Balkans," Strong Cities Network, October 9, 2019, https://strongcitiesnetwork.org/en/lpn-model-expands-to-the-western-balkans/

For more on the Centre for Common Ground, see their website: https://ccg.org.mk/ 
Balkans is among the most vulnerable regions in Europe to potential online harms. ${ }^{24}$ All Western Balkans states ${ }^{25}$ were in the bottom two quintile for media literacy and resilience to disinformation, with North Macedonia having the lowest overall score in Europe. ${ }^{26}$ Research suggests that digital literacy skills are key to building resilience against extremism, polarization, and radicalization. ${ }^{27}$ Educating effective digital citizenship will be essential in equipping young people with the understanding, tools, and confidence necessary to navigate interrelated challenges both online and offline-including challenges posed by fake news, disinformation and conspiracy theories among the young and old alike. ${ }^{28}$

Through the active development of curricula, teacher training programs, and learning resources that deliver the knowledge and skills to develop critical thinking, promote open-minded attitudes, civic engagement, and inter-cultural co-existence, governments can build greater resilience to extremist narratives, malign influence campaigns, and other online harms. While the EU's 2019 Digital Agenda for the Western Balkans does focus on the promotion of digital literacy in the region, it is important that initiatives embed notions of positive citizenship in the digital sphere and foster resilience against a range of online harms. ${ }^{29}$ These activities should not only be restricted to formal education but need to be expanded to informal education and awareness raising campaigns to ensure that not only youth, but older generations, which are equally affected by online harms, benefit from greater awareness and understanding of misinformation and extremist narratives in the online space.

\section{Conclusion}

The Western Balkans faces a number of region-specific challenges and considerations around online extremism, stemming from its unique history, diverse demographics, and geopolitical positioning, which have important implications for coherent policymaking. However, within this broader regional context, considerably divergent national and sub-national policy and threat landscapes require locally tailored responses. This policy note lays out a series of concrete policy initiatives with particular relevance to the Western Balkans, ranging from upstream efforts to build resilience to online extremism, to downstream efforts to regulate harmful online content. These responses place an emphasis on potential avenues for regional cooperation and integrated efforts, recognizing that the challenge from online extremism facing the Western Balkans is inherently transnational, and will only be systematically addressed by a combination of countrylevel responses and coordinated regional initiatives.

24 Marin Lessenski, "Just think about it: Findings of the Media Literacy Index 2019," Open Society Institute, Policy Brief 55, 2019, https://osis.bg/wp-content/uploads/2019/11/MediaLiteracylndex2019 -ENG.pdf.

25 Kosovo is not included in the study because of insufficient data.

26 Lessenski, Just think about it.

27 Louis Reynolds and Ralph Scott, Digital Citizens: Countering Extremism Online (London: Demos, 2016), https://www. demos. co.uk/wp-content/uploads/2016/12/Digital-Citizenship-web-1.pdf.

28 Ibid.

29 Be Internet Citizens provides an example of an international curriculum aimed at embedding these skills. https://internetcitizens.withyoutube.com/ 


\section{Suggested Further Reading}

\section{On Regional Extremism Challenges}

Azinović, Vlado. Regional Report: Understanding Violent Extremism in the Western Balkans. British Council Extremism Research Forum, 2018. https://www.britishcouncil.me/sites/default/files/erf report western balkans 2018.pdf

Beslin, Jelena, and Marija Ignjatijevic. Balkan foreign fighters: from Syria to Ukraine. Brussels: European Union Institute for Security Studies, 2017. https://www.iss.europa.eu/sites/default/files/EUISSFiles/ Brief\%2020\%20Balkan\%20foreign\%20fighters.pdf.

Morina, Engjellushe, Beatrix Austin, Tim Jan Roetman, and Véronique Dudouet. Community Perspectives on Preventing Violent Extremism: Lessons learned from the Western Balkans. Berlin: Berghof Foundation, 2019. https://www.berghof-foundation.org/fileadmin/redaktion/Publications/Other Resources/WB PVE/CTR PVE WesternBalkans Research Report.pdf

Stronski, Paul, and Annie Himes. Russia's Game in the Balkans. New York: Carnegie Endowment for International Peace, 2019. https://carnegieendowment.org/files/Stronski Himes Balkans formatted.pdf

\section{Country Level Profiles}

Bosnia and Herzegovina: Understanding Perceptions of Violent Extremism and Foreign Influence. Washington, DC: International Republican Institute, 2018. https://www.iri.org/resource/new-bosniaand-herzegovina-poll-citizens-pessimistic-about-future-vulnerable-outside

Bosnia's Dangerous Tango: Islam and Nationalism. Sarajevo/Brussels: International Crisis Group, 2013. https://www.crisisgroup.org/europe-central-asia/balkans/bosnia-and-herzegovina/bosnia-sdangerous-tango-islam-and-nationalism

Kosovo Wide Assessment of Perceptions of Radicalisation at the Community Level. Pristina: Republic of Kosovo, 2017. http://www.ks.undp.org/content/dam/kosovo/docs/PVE/UNDP KS-Wide\%20 Assessment eng web.pdf.

Milanović,Boris. "Mapping Extremist Discourse among Serbian 4Chan /pol/ Users." In Extremism and Violent Extremism in Serbia, 21st Century Manifestations of an Historical Challenge edited by Valery Perry, April 2019.

Qehaja, Florian, and Skender Perteshi. The Unexplored Nexus: Issues of Radicalisation and Violent Extremism in Macedonia, Pristina: Kosovar Centre for Security Studies, 2018. http://www.qkss.org/repository/ docs/Extremism in macedonia 402663.pdf.

Shtuni, Adrian. Dynamics of Radicalization and Violent Extremism in Kosovo. Washington D.C.: United States Institute of Peace, Special Report 397, 2016. https://www.usip.org/sites/default/files/SR397Dynamics-of-Radicalization-and-Violent-Extremism-in-Kosovo.pdf

\section{On Existing Regional Policy Initiatives}

European Commission. "European Commission launches Digital Agenda for the Western Balkans." Press release, June 25, 2018. http://europa.eu/rapid/press-release IP-18-4242 en.htm.

OSCE. The Role of Civil Society in Preventing and Countering Violent Extremism and Radicalization that Lead to Terrorism: A Guidebook for South-Eastern Europe. Vienna: Organization for Security and Co- 
operation in Europe (OSCE), 2018. https://www.osce.org/files/f/documents/2/2/400241 1.pdf.

Regional Cooperation Council. "Initiatives to Prevent/Counter Violent Extremism in South East Europe." August 9, 2016. https://www.rcc.int/pubs/38/annual-report-of-the-secretary-general-of-theregional-cooperation-council-2017-2018.

\section{Sources}

Azinović, Vlado. Regional Report: Understanding Violent Extremism in the Western Balkans. British Council, 2018. https://www. britishcouncil.me/sites/default/files/erf report western balkans 2018.pdf.

"Balkan Terror Trials Reveal Links to Western Europe." Balkans Investigative Research Network, January 9, 2018, https://balkaninsight.com/2018/01/09/balkan-terror-trials-reveal-links-to-western-europe-01-08-2018/.

Be Internet Citizens. https://internetcitizens. withyoutube.com/.

Bernstein, Joseph. "The Internet's United Nations Of White Nationalists." Buzzfeed News, June 24, 2015, https://www.buzzfeednews.com/article/josephbernstein/the-internets-united-nations-of-white-nationalists.

Bosnia and Herzegovina, Council of Ministers. Strategy of Bosnia and Herzegovina for Preventing and Combating Terrorism 20152020. Sarajevo: 2015. https://wb-iisg.com/wp-content/uploads/bp-attachments/6102/STRATEGIJA ZA BORBU PROTIV TERORIZMA ENG.pdf.

Centre for Common Ground. https://ccg.org.mk/.

Cosic, Jelena, Lawrence Marzouk, and Ivan Angelovski. "British Nationalist Trains Serb Far-Right for 'Online War,"' Balkan Insight, May 1, 2018. http://www.balkaninsight.com/en/article/british-nationalist-trains-serb-far-right-for-online-war--04-30-2018.

Council of Ministers of the Republic of Albania (Decision no. 930). Albanian National Strategy: Countering Violent Extremism. Official Gazette of the Republic of Albania (203/2015), November 18, 2015, unofficial translation. https://cve.gov.al/wp-content/ uploads/2018/11/strategjia-2018-me-ndryshime.pdf.

Davey, Jacob, Henry Tuck, and Amarnath Amarasingam. "An imprecise science: Assessing interventions for the prevention, disengagement and de-radicalisation of left and right-wing extremists." ISD Global, November 2019. https://www.isdglobal.org/ wp-content/uploads/2019/11/An-imprecise-science.pdf.

Dogani, Besim, and Nayla Joy-Zein. "SCN's Local Prevention Network Model Expands to the Western Balkans." Strong Cities Network, October 9, 2019. https://strongcitiesnetwork.org/en/lpn-model-expands-to-the-western-balkans/.

Eisentraut, Sophie, and Stephanie de Leon. Propaganda and Disinformation in the Western Balkans: How the EU Can Counter Russia's Information War. Berlin: Konrad Adenauer Stiftung, 2018. http://www.kas.de/wf/doc/kas 51729-544-2-30. pdf?180306092933.

Government of Montenegro, Ministry of Justice. Countering Violent Extremism Strategy 2016-2018. Podgorica: December 2015. https://wb-iisg.com/wp-content/uploads/bp-attachments/6160/Countering-violent-extremism-strategy-2016-2018.pdf.

Government of the Republic of Macedonia National Committee for Countering Violent Extremism and Countering Terrorism. National Counterterrorism Strategy of the Republic of Macedonia (2018-2022). Skopje: February 2018. https://wb-iisg.com/ wp-content/uploads/bp-attachments/6135/ct national strategy eng translation sbu.pdf. 
Government of the Republic of Serbia. National Strategy for the Prevention and Countering of Terrorism for 2017-2021. https:// wb-iisg.com/wp-content/uploads/bp-attachments/6200/Serbian-National-Strategy-for-the-prevention-and-countering-ofterrorism-for-2017-2021.docx.pdf.

Horwitz,Jeff, and DeepaSeetharaman. "FacebookExecutivesShutDownEffortstoMaketheSiteLess Divisive." WallStreetJournal,26May 2020. https://www.wsj.com/articles/facebook-knows-it-encourages-division-top-executives-nixed-solutions-11590507499.

Hussain, Murtaza. "From El Paso to Sarajevo: How White Nationalists have been Inspired by the Genocide of Muslims in Bosnia." The Intercept, 1 September 2019. https://theintercept.com/2019/09/01/bosnian-genocide-mass-shootings/.

Institute for Strategic Dialogue (ISD). Digital Policy Lab and Policy Planners Network. https://www.isdglobal.org/programmes/ policy-government-advisory/policy-planners-network/.

- $\quad$ - - Online Civil Courage Initiative. https://www.isdglobal.org/programmes/communications-technology/ online-civil-courage-initiative-2-2/.

"Joint Action Plan on Counter-Terrorism for the Western Balkans." European Commission, October 5, 2018. https://ec.europa.eu/ home-affairs/sites/homeaffairs/files/news/docs/20181005 joint-action-plan-counter-terrorism-western-balkans.pdf.

Kelmendi, Vesë, and Rudinë Jakupi. Countering the Myths of IS: How to Counter the IS Narrative Online? The Case of AlbanianSpeaking Countries. Prishtina: Kosovo Centre for Security Studies, 2019. http://www.qkss.org/repository/docs/CounteringISIS-myths-eng 724280.pdf.

Marin Lessenski, "Just think about it: Findings of the Media Literacy Index 2019," Open Society Institute, Policy Brief 55, 2019, https://osis.bg/wp-content/uploads/2019/11/MediaLiteracylndex2019 -ENG.pdf.

Milekic, Sven. "Croatia's Far Right Draws Strength from Diaspora." Balkan Insight, January 5, 2018. https://balkaninsight. com/2018/01/05/croatian-far-right-draws-strength-from-diaspora-01-04-2018/.

Regional Cooperation Council. “Balkan 'Social Media Jihadis' More Dangerous than Ex-Fighters.” December 20, 2019. https:// www.rcc.int/p-cve/news/259/balkan-social-media-jihadis-more-dangerous-than-ex-fighters.

Republic of Kosovo, Office of the Prime Minister. Strategy on Prevention of Violent Extremism and Radicalisation Leading to Terrorism 2015-2020. Prishtina: September 2015. https://wb-iisg.com/wp-content/uploads/bp-attachments/6122/STRATEGY-onPVERLT parandalim - ENG.pdf.

Reynolds, Louis, and Ralph Scott. Digital Citizens: Countering Extremism Online. London: Demos, 2016. https://www.demos.co.uk/ wp-content/uploads/2016/12/Digital-Citizenship-web-1.pdf.

"Serbia the only WB country with more trust in the government than in the EU." European Western Balkans, August 6, 2019. https://europeanwesternbalkans.com/2019/08/06/serbia-the-only-wb-country-with-more-trust-in-the-government-than-in-the-eu/.

Shehaj, Albana. "After the Pandemic: Perils and Promise for Western Balkans." Balkan Insight, April 20, 2020. https://balkaninsight. com/2020/04/20/after-the-pandemic-perils-and-promise-for-western-balkans/. 


\section{About the Note}

Authors: Milo Comerford and Simeon Dukic

Milo Comerford is Senior Manager, Policy \& Research, leading the Institute for Strategic Dialogue's (ISD) work developing innovative research approaches and policy responses to Islamist extremism. Milo regularly briefs senior decision makers around the world on the challenge posed by extremist ideologies and advises governments and international agencies on building effective strategies for countering extremism. His writing and research features frequently in international media, including the Guardian, CNN, Wall Street Journal, Sunday Times, Spectator, and New Statesman, and he has made recent broadcast appearances on BBC News, Sky News and $\mathrm{Al}$ Jazeera.

Simeon Dukic is the Manager for the Balkans \& Central Asia on ISD's Strong Cities Network (SCN). His work focuses on supporting national and local government stakeholders in strengthening national-local coordination and cooperation in preventing and countering violent extremism. Simeon has worked with a number of SCN members across the regions to establish multistakeholder and multidisciplinary Local Prevention Networks and supported the drafting and implementation tailored Local P/CVE Action Plans.

The authors are grateful to Mubaraz Ahmed and Garentina Kraja for their research and policy insights that helped shape this policy note.

The views expressed in this publication are those of the authors. They do not necessarily reflect the views of the RESOLVE Network, the U.S. Institute of Peace, or any entity of the U.S. government.

RESOLVE NETWORK better research.informed practice. improved policy on violent extremism. www.resolvenet.org $\square$ ( ) in. 